DOI 10.15826/qr.2017.1.210

УДК 314.018+351.755(571.120)

\title{
URBAN OCCUPATIONS IN A SIBERIAN CITY (TOBOLSK, 1897)*
}

\author{
Elena Bryukhanova** \\ Vladimir Vladimirov \\ Altai State University, \\ Barnaul, Russia
}

The article studies the late $19^{\text {th }}$-century occupational structure of Tobolsk in the context of other major Siberian cities. Many urban centres were strongholds for governing this huge territory, and Tobolsk was a typical provincial capital in this regard. In the most economically developed Western and Southern Siberian provinces, cities were not only administrative hubs, but also cultural and economic centres. The authors look at how urban populations were distributed among different occupational groups and social classes, and what role gender and family relations played in terms of employment. This is important, as it may help understand whether Russia's huge eastern provinces were ready for the transformations which started just two decades after the period whence the main source material of the article originates. The research is based on the first general census of the Russian Empire in 1897. The archives have not preserved primary census manuscripts as a unified collection: so far, only scattered manuscripts have emerged. Clearly, the use of the individual-level nominative census data found for Tobolsk considerably broadens the scope of the research, which was previously limited to aggregate data. The aggregate data provide an opportunity to characterise employment in Siberian cities more generally, demonstrating the occupational specificity of the 'military' and 'agrarian' cities as well as the provincial centres of Western and Eastern Siberia. The authors more closely analyse the nominative 1897 census data using the database 'Tobolsk Population in 1897', which contains information about $92.5 \%$ of employed citizens. The individual-level data made it possible to reconstruct the age and gender structure of the economically active population of the provincial centre, to study the occupations of different estate groups, to look into specific features of secondary occupations, and to see the family's influence on the choice

* Citation: Bryukhanova, E., Vladimirov, V. (2017). Urban Occupations in a Siberian City (Tobolsk, 1897). In Quaestio Rossica, Vol. 5, № 1, p. 56-73. DOI 10.15826/qr.2017.1.210. Цитирование: Bryukhanova E., Vladimirov V. Urban Occupations in a Siberian City (Tobolsk, 1897) // Quaestio Rossica. Vol. 5. 2017. № 1. P. 56-73. DOI 10.15826/qr.2017.1.210.

** The authors would like to thank Professor Gunnar Thorvaldsen (University of Troms $\varnothing$ ) for his valuable scholarly advice and support.

(C) Bryukhanova E., Vladimirov V., 2017 Quaestio Rossica • Vol. 5 • 2017 • № 1, p. 56-73 
of occupation. All the employment data on the Siberian urban population were coded according to the HISCO standard.

Keywords: Russian Empire; Siberia; Tobolsk; First Russian Imperial Census of 1897; occupations; Historical International Classification of Occupations.

Рассматривается профессиональная структура города Тобольска конца XIX в. Сибирь была самым масштабным регионом Российской империи со слабо развитой сетью городов, большинство из которых выполняли роль опорных центров для административного управления огромной территорией. В наиболее освоенных и развитых в хозяйственном отношении западных и южных губерниях Сибири города становились не только административными, но и культурными, и экономическими их центрами. Вопрос представляется актуальным для понимания готовности сибирских губерний к тем общественным трансформациям, которые начались спустя два десятилетия после рассматриваемого периода. Особенностью исследования является использование персональных данных Первой всеобщей переписи населения Российской империи 1897 г. На уровне персоналий оно позволяет существенно расширить исследовательский диапазон, ранее ограниченный опубликованными агрегированными материалами. C их помощью дана характеристика занятости городского населения крупных сибирских городов, показана специфика занятости «военных», «аграрных» городов, а также губернских центров Западной и Восточной Сибири. Обработка данных переписи 1897 г. на индивидуальном уровне производилась с помощью базы данных «Население Тобольска в 1897 г.», включающей сведения о 92,5 \% горожан, имевших самостоятельные занятия. Персональные данные позволили провести реконструкцию возрастной и гендерной структуры экономически активного населения губернского центра, выявить особенности занятости представителей разных сословных групп, специфику дополнительных занятий городского населения, определить влияние семьи на выбор сферы деятельности человека. Все сведения о занятиях населения городов Сибири, в том числе Тобольска, были закодированы с помощью Historical International Standard Classification of Occupations.

Ключевые слова: Российская империя; Сибирь; Тобольск; Первая всеобщая перепись населения Российской империи 1897 г.; занятия населения; Международная историческая классификация занятий.

Around 1900, Siberia was the largest region of the Russian Empire, occupying $58 \%$ or 12.5 million $\mathrm{km}^{2}$ of its territory. Nikolay Yadrintsev, a famous publicist and ethnographer in the late $19^{\text {th }}$ century, authored the book Siberia as a Colony in Terms of Geography, Ethnography, and History. There he defined the region's borders: "Siberia occupies all the northern part of Asia and stretches to the Arctic Ocean, in the east it reaches the Pacific Ocean, its southern border is the Chinese Empire, in the south-west it borders 
on the Middle Eastern part of the Russian Empire and in the north-west and the west it is separated from European Russia by the Urals" [Ядринцев, с. 6].

This huge territory was home to only $4.6 \%$ (5.7 million people) of the Empire's population. The density registered by the 1897 census was less than 1 person (0.46) per $\mathrm{km}^{2}$. Geographically, Siberia was divided into a western and an eastern part, and for administrative purposes into the eastern Irkutsk governorate ${ }^{1}$ (made up of Irkutsk, Yeniseisk, and Yakutsk Oblasts), ${ }^{2}$ the Priamurskoe governorate (Amur, Primorsk, and Zabaikalsk provinces), Sakhalin Island, and western Tobolsk and Tomsk provinces ${ }^{3}$ [Учреждение Сибирское, с. 471-472]. The provinces and big cities of Siberia are presented in fig. 1.

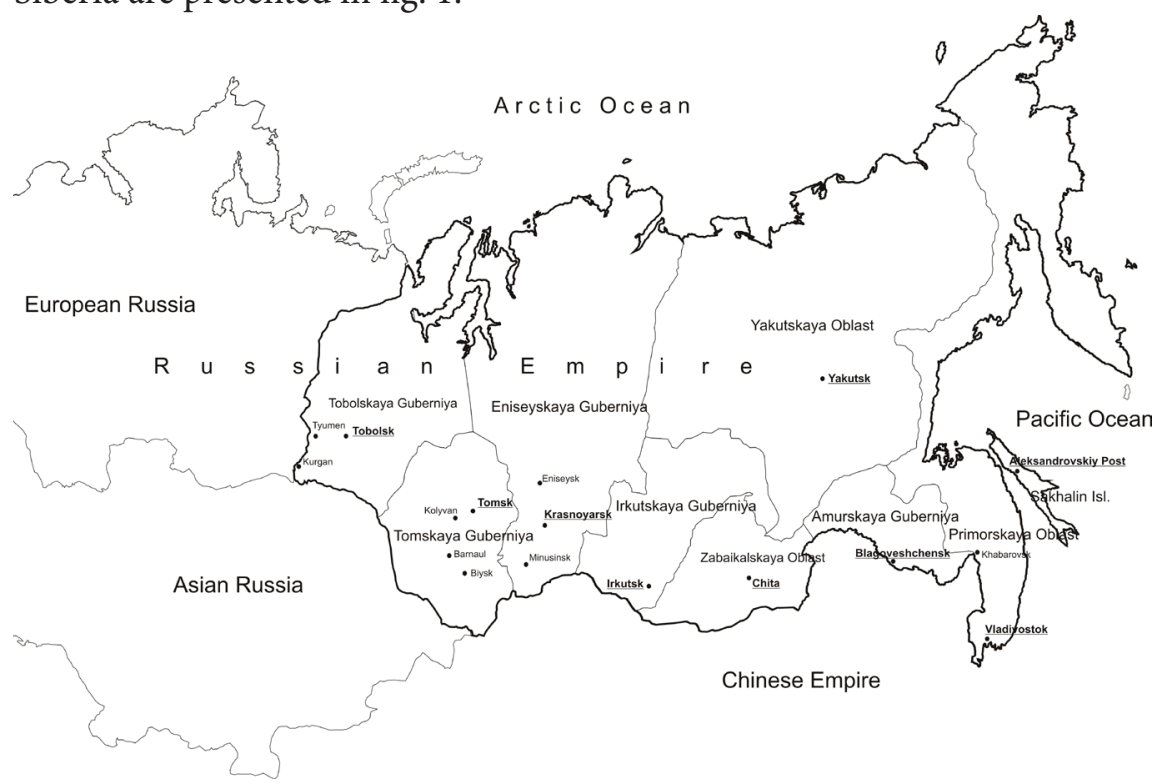

Fig. 1. The provinces and big cities of Siberia in 1897

In addition to its geography and location, Siberia had a number of socioeconomic peculiarities. In the late $19^{\text {th }}$ century, the region attracted substantial voluntary immigration. The well-known economist and statistician Alexander A. Kaufman stated that over 700,000 persons moved to Siberia in the decade before the 1897 census, only $10 \%$ of whom returned [Кауфман, с. 271]. The main destinations in Western Siberia were areas like the "Tobolsk forest steppe" and the "Kabinetskaya datcha", a fertile part of the Altai mining okrug (district) ${ }^{4}$ in Tomsk province. In Eastern Siberia,

${ }^{1}$ A governorate (gubernatorstvo) was an administrative unit in the Russian Empire which included several (usually three) sub-governorates or oblasts.

${ }^{2}$ Oblast was the name of some administrative units corresponding to guberniyas. This word usually denoted newly annexed territories. Hereafter - province.

${ }^{3}$ A guberniya was the principal administrative subdivision of the Russian Empire. Hereafter - province.

${ }^{4}$ An okrug was a territorial unit in an oblast similar to a uyezd (district) in a guberniya. Hereafter - district. 
the most attractive regions were Amur, Yeniseisk, and Irkutsk provinces [Семенов, с. V].

One important group of immigrants were the exiles. From 1807 to 1899, 864000 exiles and their families went to Siberia [Лучинский, с. 761]. The biggest convict prisons of the $19^{\text {th }}$ century were located in Siberia, e. g. in Tobolsk and the Nerchinsk Penal Colony (Zabaikal province). Convicts made up over $8 \%$ of the population of Nerchinsko-Zavodskoy district of Zabaikal province. Penal servitude was defined as "forced labour done in the state's favour by the most severe criminals" [Слиозберг, с. 756]. In Tobolsk, the initial major group of exiles were Swedish prisoners of war, who arrived in the early $18^{\text {th }}$ century [Thorvaldsen, 2008].

A further peculiarity of Siberia's social structure was the complex ethnic composition of the region. There were over 100 ethnic groups, as one of the best-known ethnographers of the early $20^{\text {th }}$ century reported [Патканов, c. VI]. However, according to the 1897 census, the Russian population of Siberia made up $80.9 \%$, and most of the urban population was Russian.

By the time of the 1897 census, 50 settlements were considered cities, containing $8.2 \%$ of the population. Initially, Siberian cities were strongholds for governing the territory and controlling its development, but in the 1890 s such "foothold" cities were characteristic of the northern and coastal regions of eastern Siberia, while many cities in the western and southern provinces were primarily cultural and economic centres [Naumov, p. 130].

The late $19^{\text {th }}$ and early $20^{\text {th }}$ centuries witnessed great economic changes in Siberia: this was determined by the infrastructural development of traffic arteries and trade routes, which had moved to the south and crossed the territory of the "main settlement belt" by the late $19^{\text {th }}$ century [Лаппо, с. 280]. Especially intensive was the construction of the Trans-Siberian Railway. These processes influenced the urbanisation and economy of the territory. Thus, the 1897 census registered the results of a unique epochal change. Many historians consider the 1890s in Siberia to be a transitional stage away from the post-reform period, which had begun after the abolition of serfdom in 1861 [Зиновьев, с. 29-30; Шиловский, c. 6; Скубневский, Гончаров, с. 162]. These changes naturally influenced the occupational structure of urban populations in Siberia. In addition to our research questions about the occupational structure revealed by the census, we also want to hint at a wider issue in Russian historiography: to what extent did such modernisation prepare the Asian part of Russia for the dramatic events and reforms which occurred only two decades after the census?

\section{Siberian occupations in the 1897 census}

The largest and most complex source for studying Russian occupations in the late $19^{\text {th }}$ century is the first general census, taken on 28 January 1897. The census was prepared at two international statistical conferences in Saint Petersburg: relevant experience was also taken from a comprehensive, 
century-long collection of nominative family data in taxation lists and ministerial records. Like in the British Empire, the census was simplified by sticking to the de facto enumeration principle; people had to be listed and counted simply where they met the census takers on the census day [Thorvaldsen, 2006].

The fourth regular session of the International Statistical Institute, held in 1897 in Saint Petersburg, recognised the All-Russian Census as the largest in the world, since it included 130 million persons [Елисеева, Попова, с. 85; Rowney, Stockwell, p. 219]. The census data were tabulated using statistical Hollerith machines [Rowney, Stockwell, p. 219] in a process that took eight years: some of the census results were translated into French [Первая Всеобщая перепись...]. After the release of the main results in 1905, the aggregates became one of the most popular statistical data series used in both Russian and foreign research [Kasatkina, Marcinkevicius]. The central variables were age [Rowney, Stockwell], ethnic characteristics based on language, marital status, and religion [Lewis, Rowland, Clem; The Cambridge History of Russia]. Using data on employment was hampered by several factors. Firstly, the distribution of occupation groups was skewed [Кадомцев, с. 19-20]. Second, the 1897 census publications stressed an industrial classification of occupation groups [Final Report Summary, p. 28]. Thirdly, the 1897 census aggregates used only a two-level division of 65 groups and 390 sub-groups. For this reason, researchers have offered from 6 to 17 of their own 'major' groups, which were determined by their different approaches to examining the occupational structure of the region [Ленин, с. 501505; Миронов, с. 307; Скубневский, Гончаров, с. 267; Spitzer]. In our research, we primarily used the "major" groups provided by the HISCO (Historical International Standard Classification of Occupations).

The question about occupation ("Occupation, trade, business, office or service") was the fourteenth on a census form where the census taker had to register: a) their main occupation (which provided the main means of living), b1) secondary or auxiliary occupation, and b2) military position ${ }^{5}$. The aggregation of occupations in the 1897 census produced four tables: 1) Population by occupation and age group, 2) by uyezd (district) and city, 3 ) by ethnic group, which was determined on the basis of native language, and 4) population occupied in agriculture, nomadic economy (fishing and hunting), and commercial trades. Each table distinguished between males and females and provided the number of family members who were selfemployed individuals.

The 1897 census results were published in nine volumes presenting data on 65 occupation groups for all Siberian districts, cities, and administrative centres. There was thea four-volume Population Distribution by Main Occupations and Age Groups in Separate Territories, thea two-volume Number and Composition of Russian Workers, with data on the provinces

\footnotetext{
${ }^{5}$ For the census forms, see: [Edlund].
} 
as a whole, and thea two-volume Total Summary of the... Census Results... 1897 [Общий свод...], which has statistics for Siberia as a whole as well as for individual Siberian provinces and Sakhalin Island. The aggregated occupational data from all these published sources were the basis for the database Professions and Occupations of the Russian Empire in the Late $19^{\text {th }}$ to Early 20 th Centuries [Профессии и занятия населения Российской империи, 2014], which can be accessed freely [Профессии и занятия населения Российской империи, 2017]. All statistics for this article were derived from this database.

The sources for the study of occupations in Tobolsk are published aggregated data and archival documents. The latter include the 1897 census manuscripts preserved in the State Archive in Tobolsk city [Государственное учреждение...]. Such historical census lists have generally not been preserved in Russia, and they were considered lost for a long time. The information that some regional archives were storing copies of individual 1897 census manuscripts appeared only in the 1990s. Discussions on the safe-keeping of the 1897 census manuscripts in various regional archives can be found in articles by both Russian [Литвак, с. 123] and foreign researchers [Edlund, p. 33]. However, surveys have not yet been conducted. As far as is known, the collection of 1897 census manuscripts in the Tobolsk archive is the most fully preserved.

From these original archival materials, we have created thea unique database "The Tobolsk Population in 1897". This includes all 10203 citizens with a registered occupation or social status. 10124 persons have records about a primary occupation and 1637 about a secondary one, out of whom 79 named only the latter. The sample in the database makes up $50 \%$ of the total population: $92.5 \%$ of these people provided some kind of occupational data. The database does not cover students or the occupants of orphanages, asylums, poorhouses, and hospitals. However, records which marked one's former status as a prisoner and those which noted the civil occupations of the members of the Tobolsk infantry battalion are included. The database has the following information about each citizen: first name, surname, patronymic (if available), sex, age, marital status and relation to the householder ("owner himself", "wife", etc.), estate, ${ }^{6}$ native language, religion, literacy and educational institution, primary occupation, and secondary occupation. The notes provide information about injuries, military service, and other data.

In order to unify and compare the aggregated and personal data, we encoded all the 1897 occupations in Siberian cities according to HISCO. This was carried out using the major HISCO groups. HISCO's Additional Classification was used as well, including such groups as "earning a living from capital or immovable property or money from parents or relatives", "earning a living from the treasury and

${ }^{6}$ Estate (soslovie) refers to the social estate, which here means a group of people legally distinguished from the rest of population: the distinction was hereditary. 
public institutions as well as private persons' money", and "unknown occupations". Note that in order to optimise the employment structure and study the social peculiarities of small groups, we merged those employed in administrative management and clerical work into groups $2-3$, while groups such as "the armed forces" and "the imprisoned" were kept separate [Брюханова, Сарафанов, Владимиров, Колдаков, c. 262; Владимиров, Сарафанов, Щетинина, с. 32]. The results of the HISCO group comparison between the aggregated and the personal data are presented in fig. 2. This demonstrates a high correlation between the aggregated and the personal data: the result for the nine groups is 0.85 .
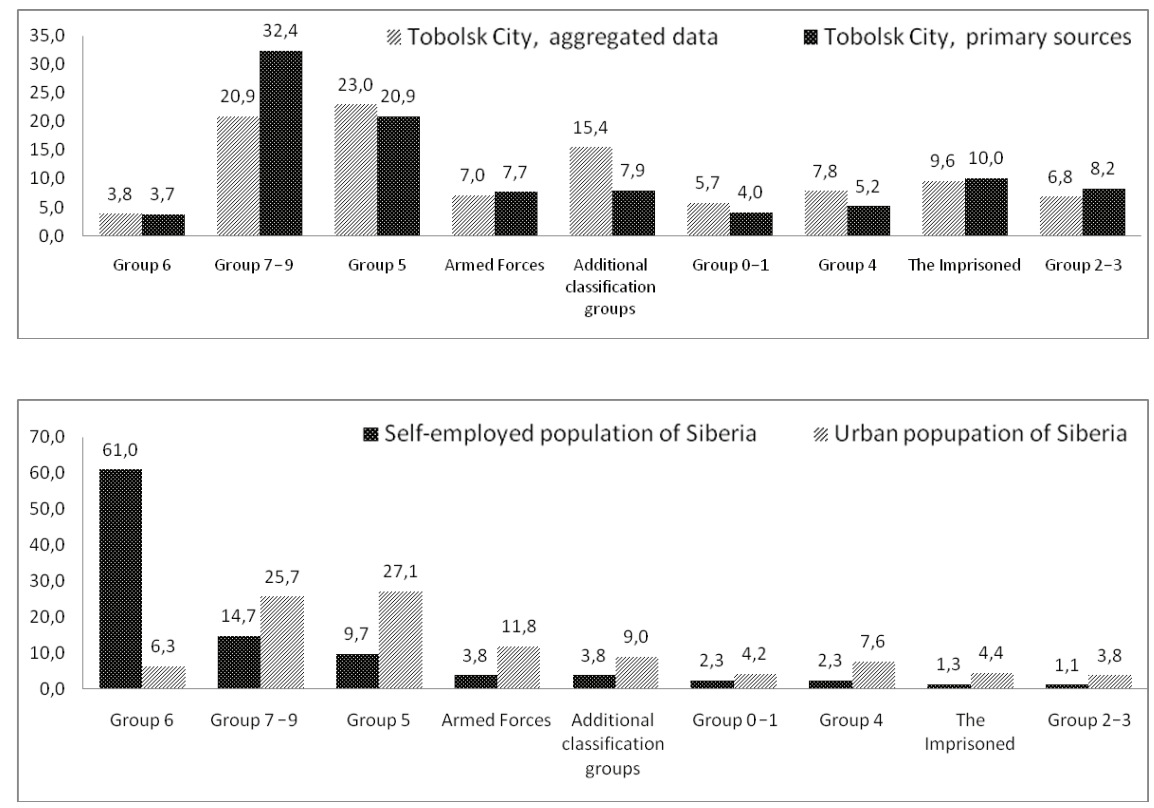

Fig. 2. Occupations of Siberia and the city of Tobolsk by major HISCO groups: $a$ - Tobolsk City, $b$ - Siberia; ${ }^{7}$

HISCO groups: 6 - agricultural, animal husbandry, and forestry workers, fishermen, and hunters (groups 17-21);7-9-production and related workers, transport equipment operators and labourers (groups 22-37, 38-44); 5 - service workers (groups 13, 60-62, $64) ; \mathrm{AF}$ - the armed forces (group 4); Ad. Cl. - additional classification groups (groups 14, 15,65 ); $0-1$ - professional, technical, and related workers (groups 3-12, 36, 63); 4 - sales workers (groups 46-59); Impr. - the imprisoned (group 16); 2-3 - administrative and managerial workers, clerical workers (groups 1, 2, 45).

7 The $7.5 \%$ difference in the Additional Classification group is accounted for by the exclusion of data on over 500 students as unoccupied.

The $11.5 \%$ difference in HISCO group 7-9 "production and related workers, transport equipment operators and labourers" is down to different counting systems: the authors' calculations show that this group includes all production occupations irrespective of the position in the occupation and in the household as well as those occupations which were recorded as being primary ones. 


\section{Tobolsk among Siberian cities in the late $19^{\text {th }}$ century}

Tobolsk was the Siberian capital from the $16^{\text {th }}$ to the late $19^{\text {th }}$ century. On the one hand, it was far from the transport and economic centres concentrated further south. On the other hand, it was still an important administrative hub as well as a developed city. Tobolsk was one of eight Siberian cities with a population exceeding 20000 people: the others were Blagoveshchensk, Vladivostok, Krasnoyarsk, Tobolsk, Tyumen (the district city of Tobolsk province), and Barnaul (in the Altai district in Tomsk province). The economic and cultural centres Tomsk and Irkutsk had populations of over 50 000. This group was followed by seven cities with a population of over 10000 people which stood out economically and culturally: among them was Chita, the centre of Zabaikal province. Together, these 15 cities were home to $74 \%$ of the Siberian population. Other cities were small or village-like; eight cities in Eastern Siberia had fewer than 1000 residents. Such settlements had been granted their city status and corresponding administrative structure via the 1892 city government law, the Gorodovoye Polozheniye [Города и поселения в уездах, с. 1].

The distinctive feature of major Siberian cities including Tobolsk was the dominance of two groups in urban economic life. These were HISCO group 5 "service workers", with from 19 to $31 \%$ of the employed, and groups 7-9 "production and related workers, transport equipment operators and labourers", with from 19 to $42 \%$ of the employed. The overall proportion for Tobolsk was $54 \%$. The dominance of these occupations made such urban settlements qualitatively different from those considered cities only because they had been conferred administrative powers.

The large- and medium-sized Siberian cities had a number of features that were determined by the region's territorial and economic specificity. First, in the "military cities" (Vladivostok, Khabarovsk, Chita, and Blagoveshchensk), the social structure was dominated by "the armed forces" (with from 13 to $33 \%$ of the employed), which skewed the sex-age composition (males made up 60 to $84 \%$ of the population) and caused a high level of employment (up to $82 \%$ ). Such cities were necessary in Western Siberia for border control and administration of the vast underdeveloped territory. Second, the major "agrarian cities" in the developed regions (Biysk and Kolyvan in Tomsk province, Minusinsk in Yeniseisk province) were characterised by high employment in the agrarian sector (from 12 to $21 \%$ ), low overall employment (28-32\%), and a small surplus of women (51-52 \%). The third group of major cities includes those involved in trade (from 5 to $10 \%$ of the employed). Trade was important in the economy of those Western Siberian cities (Kurgan, Tyumen, Barnaul, Biysk, and Tomsk) which were centres for Siberia’s commerce with European Russia. Moreover, the eastern city Blagoveshchensk took part in international trade (10\% of some 30000 people were citizens of China, Korea, and Japan: half of them were occupied within trade). 
The provincial centres (Tobolsk, etc.) were somewhat special among the big Siberian cities, as they differed with respect to the number of people employed in industrial production, which included both small plants in the manufacturing sector and big plants in the mining industry (over $50 \%$ ), and a surplus of men ( $59 \%$ cent on average). These were administrative and cultural centres, and a concentration point for government and social institutions, including religious, medical, educational, and cultural establishments. In Tobolsk in 1897, there was a consistory and an episcopal palace, a building for the provincial public office with a court and a police department, 25 churches, 20 educational institutions, 5 charitable and 10 medical institutions, a poorhouse, and city and jail hospitals [Алисов, c. 264; Латкин, с. 384]. The goals of public management as well as demand for medical and qualified technical workers, teachers, and professionals in the provincial centres led to a great deal of employment in group 0-1 "professional, technical and related workers" (4-6\%) and group 2-3 "administrative and managerial workers, clerical workers" (4-8 \%). This is not characteristic of the military and administrative centres of the underdeveloped territories (Blagoveshchensk and Vladivostok). Tobolsk could boast one of the highest rates of those employed in groups $0-1$ and $2-3-12.4 \%{ }^{8}$. The reverse side of the concentration of such institutions in the provincial centres was a high degree (over $10 \%$ ) of people earning a living via tax incomes, public institutions, and the capital of private persons. $12.6 \%$ of Tobolsk's population were coded within the "Additional Classification" group.

Thus, in the late $19^{\text {th }}$ century, Tobolsk was a typical provincial administrative centre in Western Siberia, with its citizens mostly involved in traditional occupations. A peculiar feature that touched on social composition was the quartering of the Tobolsk infantry battalion in the city (over 800 people of high and low ranks), a prison fortress, and the two biggest Siberian convict prisons, with over 1000 arrestees.

\section{Social structure and estates in Tobolsk, 1897}

The 1897 census enumerated 20,425 persons de facto in Tobolsk [Пepвая Всеобщая перепись, т. 46, с. 1; Thorvaldsen, 2006]. The nominative data show that 11028 (54\%) of them had occupations: fig. 3 displays the sex and age distribution according to employment status.

Males aged from 20 to 60 dominated the workforce: $95 \%$ of them had occupations according to the census. A similar gender and age structure characterised most Siberian cities. Two of the reasons for this skewed sexage pyramid were the military and prisoners, leading to a sharp increase in the male population aged 20-29. In addition, the major cities and provincial centres attracted seasonal and other temporary workers, especially in-migrating peasants in the winter when the 1897 census was taken.

\footnotetext{
${ }^{8}$ Calculated by the authors in the [Население Тобольска в 1897 г.].
} 

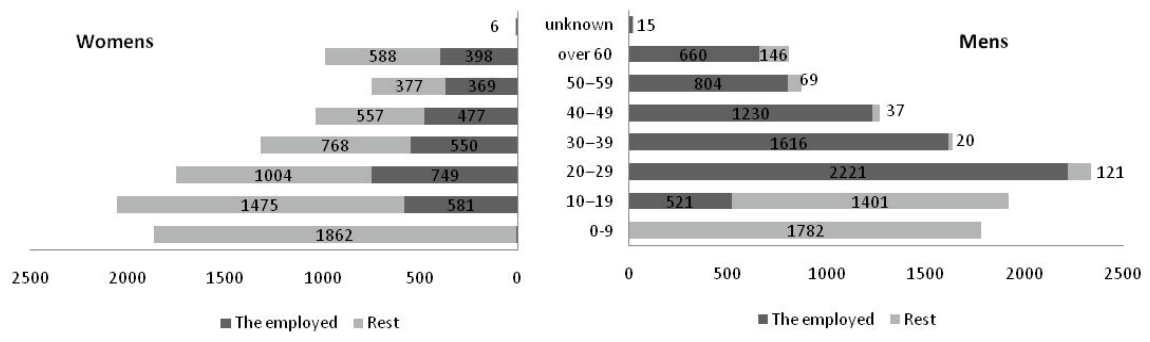

Fig. 3. Sex and age distribution by employment status in Tobolsk, 1897 census: $\mathrm{a}$ - womens, $\mathrm{b}-$ mens $^{9}$

This was true for men aged 20-50 and single women under 29. In Tobolsk, male and female employment made up 72 and $34 \%$ respectively. This share for the men was in line with the average employment of provincial centres, whereas the female employment was a bit higher and corresponded to that in the biggest cities such as Tomsk and Irkutsk, which, like Tobolsk, possessed female educational institutions.

As expected, an important factor limiting female employment was marriage. Only $28 \%$ of married women had paid occupations. The most common age of married women was 20-39. Out of 3,071 females of this age, $63 \%$ were married. For the males, the most common age to be married was 30-49; out of 2903 males of this age, $73 \%$ were married. Being single, divorced, or widowed changed a woman's social position and forced her to work in order to fend for herself and her family. Thus, $67 \%$ of the widows and $47.8 \%$ of the divorced women had occupations. Among single women, $80 \%$ were aged 10-29 and might have been provided for by their parents: as such, only $36.8 \%$ went to school or worked (fig. 3 leaves out about 300 female students in Tobolsk educational institutions due to lacunae in the database).

Military installations, migrating peasants, and prisoners influenced the social structure of the provincial centres. The urban estates dominated the population of big Siberian cities: petty bourgeoisie, merchants, and freemen, who made up $40 \%$ on average, took part in all economic sectors, as is shown in table.

Members of the rural estates (37.4\% of the population in Tobolsk) were numerous, especially in the industrial and service sectors. Such social heterogeneity was rarer in the "agrarian cities" of Western Siberia, where the urban estates equalled from 60 to $82 \%$. In Tobolsk, the presence of a large rural estate was due to the labour mobility of peasants. Such mobility also explains the high employment among peasants, $45.2 \%(52.2 \%$ of conscripted peasants are included): in the non-urban areas, the average peasant employment was $25 \%$. As for position in the household, $24.5 \%$ of the peasants were labourers or servants: only $27 \%$ had their own household, while $18 \%$ of working peasants lived in hostels or rented rooms.

\footnotetext{
${ }^{9}$ Calculations were made in [Население Тобольска в 1897 г.] (employed population) and [Первая Всеобщая перепись населения Российской империи 1897 г., т. 46, c. 10-11] (general population).
} 


\section{Occupations of social estate groups in Tobolsk, 1897 census $^{10}$}

\begin{tabular}{|l|c|c|c|c|c|c|c|c|}
\hline \multicolumn{1}{|c|}{$\begin{array}{c}\text { Status } \\
\text { groups } \\
\text { Occupation } \\
\text { groups } \\
\text { (total, \%) }\end{array}$} & $\begin{array}{c}\text { Noblemen } \\
\text { (by birth } \\
\text { and award), } \\
\text { civil } \\
\text { servants }\end{array}$ & Clergy & $\begin{array}{c}\text { Freemen, } \\
\text { merchants, } \\
\text { petty bour- } \\
\text { geoisie, and } \\
\text { other urban } \\
\text { estates }\end{array}$ & Peasants & Natives & $\begin{array}{c}\text { Other } \\
\text { estates }\end{array}$ & $\begin{array}{c}\text { Estate } \\
\text { un- } \\
\text { known }\end{array}$ & N \\
\hline Groups 0-1 & $41.1^{11}$ & 20.9 & 23.1 & 9.5 & 0.7 & 1.9 & 2.7 & 411 \\
\hline $\begin{array}{l}\text { Additional } \\
\text { classification } \\
\text { groups }\end{array}$ & 33.4 & 1.8 & 35.7 & 20.5 & 0.3 & 5.4 & 2.8 & 775 \\
\hline Groups 2-3 & 39.5 & 1.4 & 39.4 & 16.1 & 1.0 & 1.6 & 1.1 & 838 \\
\hline Group 4 & 0.6 & 0.0 & 74.0 & 18.8 & 2.3 & 3.4 & 1.0 & 526 \\
\hline Group 5 & 4.8 & 0.3 & 32.6 & 57.4 & 0.6 & 3.2 & 1.1 & 2129 \\
\hline Group 6 & 1.3 & 0.0 & 16.5 & 74.9 & 5.0 & 2.4 & 0.0 & 382 \\
\hline Groups 7-9 & 3.4 & 0.5 & 45.1 & 45.6 & 1.3 & 3.6 & 0.6 & 3305 \\
\hline $\begin{array}{l}\text { Without oc- } \\
\text { cupations, } \mathrm{n}\end{array}$ & 3 & 4 & 13 & 9 & & 1 & 0 & 30 \\
\hline $\begin{array}{l}\text { Total number } \\
\text { of the em- } \\
\text { ployed, n }\end{array}$ & 986 & 140 & 3351 & 3455 & 98 & 277 & 89 & 10202 \\
\hline Among them: & 4 & 1 & 99 & 540 & 5 & 366 & 9 & 1024 \\
\hline Exiles, n & 1 & 1 & 56 & 696 & 2 & 3 & 23 & 782 \\
\hline Military men, N & 445 & 751 & 8289 & 7649 & 252 & 914 & 125 & 20425 \\
\hline $\begin{array}{l}\text { Total for } \\
\text { Tobolsk }{ }^{12}\end{array}$ & 18.6 & 40.4 & 45.2 & 38.9 & 30.3 & 71.2 & 54.0 \\
\hline $\begin{array}{l}\text { The share of } \\
\text { employed } \\
\text { in the estate } \\
\text { group, \% }\end{array}$ & 40.3 & & & & & & & \\
\hline
\end{tabular}

The most attractive occupations for both the immigrating and urbanborn peasants waswere groups 5 "service workers" (57.4\% of the employed in the group) and 7-9 "production and related workers, transport equipment operators and labourers" (45.6\%). Peasants worked as servants in private houses and institutions, cabmen, and labourers. Most peasant estate occupations are covered by group 6 "agricultural, animal husbandry and forestry workers, fishermen and hunters" (74.9\%), particularly farming and fishing.

${ }^{10}$ The calculations were made in the database [Население Тобольска в 1897 г.]: military men and the imprisoned are shown individually.

${ }^{11}$ The share of the estate representatives in the HISCO group (without military men and the imprisoned).

${ }^{12}$ Data from: [Первая Всеобщая перепись населения, т. 46, с. 46-47]. 
The urban estates - noblemen and civil servants - had a $40 \%$ employment rate. Out of 2445 noblemen and civil servants, $56.7 \%$ were household heads. $41 \%$ of 8000 members of the petty bourgeoisie had their own household while only $14 \%$ were registered as servants (only $3 \%$ of the noblemen in Tobolsk were servants). These social estates were also well represented in HISCO groups 0 and 1 (41\% - noblemen, $23.1 \%$ - petty bourgeoisie) and group 2-3 (39\% - civil servants and noblemen and petty bourgeoisie). These occupations demanded special education, talent, and occupational skills. Clerical and church officers were represented only in groups 0 and 1 , with $61 \%$ of the clergy having such an occupation. It is interesting that about half of the urban estates were employed within groups 7-9 (1 489 from 3351 persons), but merchants and petty bourgeoisie played the main role in group 4, making up $74 \%$ of those employed in trading.

On the basis of the nominative data, we singled out the 782 military personnel and the 1024 exiles. They are registered in the census with their present and former occupations. Half of the military men belonged to the peasantry while among the 1024 imprisoned, only 336 were actually noted as "exiles": the rest listed their social estate at birth (51\% in the peasant estate). Additional groups include people drawing a pension, those who received a living in private homes and charitable institutions, and those who lived off donations or their own capital $-69.2 \%$ of this group were noblemen, civil servants, and members of the urban estates.

To sum up employment among the social estates, noblemen and civil servants mostly belonged to HISCO groups $0-1$ and $2-3$, the clergy were only in group $0-1$, and the peasants were in groups 5 and 7-9. For many peasants, these occupations were temporary. The members of the urban estate worked in all sectors of the urban economy.

Individual-level data provide an opportunity to compare primary and secondary occupations within the HISCO groups. $15 \%$ of the Tobolsk working population had additional sources of income. Among them were 447 women who listed their primary social status as "with the husband", "with a brother", or "pension". Their "secondary" income came from "private obstetric practice", "private teaching", or work as laundry girls, needlewomen, knitters, etc. Many with additional earnings worked in agriculture: they made up 254 persons, or $25.4 \%$, including military men who farmed as a primary occupation. The smallest share of people with additional earnings can be found in group 5 "service workers" (179 people, or $8.5 \%$, of those employed in group 5 , which includes men who listed military service as their primary occupation) and groups 7-9 "production and related workers, transport equipment operators and labourers" (287 people, or $8.7 \%$ ).

The combination of individual-level primary and secondary occupation data was especially illuminating for the military. The Tobolsk infantry battalion was registered in a separate list, which recorded a primary civil occupation and a secondary military one. Most of the soldiers stated "farming" as their primary occupation and were thus placed in HISCO 
group 6 "agricultural, animal husbandry and forestry workers, fishermen and hunters". During military service, a number of conscripts received additional training (in medical practice for instance), thus receiving an opportunity to become socially mobile. Some chose primary and secondary occupations in the same HISCO group. In group 0-1 for instance, the primary occupation was "provincial government, agrotechnician", while the secondary occupation was "botany teacher at a paramedic school": for groups 7-9, the primary occupation was "coach driving" and the secondary one was as a "leatherworker". The most widespread additional earnings were in the service sector, handicrafts, and as day-labourers.

An additional aspect to study with individual-level data is the influence of kinship and cohabitation. The 1897 census registered 54 households that were not bound together by kinship. These were artels, workmen's cooperatives, and workers and servants living apart from their masters (402 people all in all). There were 406 households with one household head and some servants (only 892 people). Family households (i. e. households where relatives lived together) numbered 3059 , with 16413 persons [Пepвая Всеобщая перепись, 1905a, т. 46, с. 7, 10]. The "Tobolsk Population in 1897" database contains 1040 family households with 2609 persons having an occupation. These family households were used to form one male and one female sample. The male sample was from the 173 households with information about the occupations of 173 fathers and their 205 sons. The female sample was from the 100 households with two or more female relatives including wives, daughters, sisters, nieces, daughters-in-law, sisters-in-law, etc. Moreover, a third sample was constructed with 160 potential father-son relations (232 sons) across households, linking them via the father's first name and the son's patronymic and the age difference. When the fathers and sons were distributed across the HISCO groups, it seems that cohabitation did not influence the sons' choice. In the case of cohabitation in the same household, $34 \%$ of the sons followed in their fathers' footsteps: when they lived in separate households, the figure was $37 \%$. Groups 7-9 were chosen by $50 \%$ of the sons: the other $50 \%$ chose groups $2-3$. Thus, these groups were the most attractive for sons who were transitioning to other HISCO groups. In both cases, the most common "father" occupations were in the service sector (group 5) and trade (group 4). On average, $25 \%$ of the sons moved upward socially. The study of female employment clusters by household gave significantly different results. In 70 of the 100 sampled households, two or more women chose an occupation in the same HISCO group, primarily in groups 5 and 7-9. Often they worked in complementary trades, especially if there were more than three females in a household [Брюханова, Владимиров, с. 124]. For instance, in a household with six women consisting of three sisters (one of them the householder) and three nieces, all were occupied in fur tailoring (HISCO code 7-62.00). Thus, senior household members more frequently influenced female employment, whereas sons' choice corresponded to their fathers' occupational group only in about one third of the cases. $25 \%$ of the 
other sons managed to move upwards socially: the most socially mobile sons were classified in HISCO's service and trade sectors.

In the late $19^{\text {th }}$ century, the building of traffic infrastructure, increasing migration to the south of Western and Eastern Siberia, and the development of the Far Eastern territories led to the growth of provincial centres and other Siberian cities. In the northern and border regions of Eastern Siberia, many cities were established as administrative and military hubs without other economic development. In the southern agricultural regions, we find both agrarian centres and major towns with other economic activities. We have especially focused on Tobolsk, which was situated to the north of the main transportation routes and migration streams. It still had significance because it retained its administrative, historic, cultural, and economic functions. Therefore, the 1897 census aggregates show Tobolsk as a typical provincial centre among the others in Western and South-eastern Siberia.

The unique nominative census data found for Tobolsk shows the dominance of the male workforce aged 20-50, high employment rates, and the dominance of the service sector. The peculiarities manifested by Tobolsk were the presence of a major military unit and the biggest Siberian convict prisons, both of which influenced the social composition of the city. The conscripts, the imprisoned, and the seasonally migrating workers formed a major peasant population with a high employment rate. The urban estates noblemen and civil servants - made up a big share of the city's permanent population and took part in all urban economic sectors.

The nominative data allowed us to study the occupations of the estate groups, including secondary occupations. The primary occupations, for instance among the military, could provide both income opportunities and upward social mobility. The individual's social estate could determine to some extent the choice of occupation, as was clearly the case for noblemen, civil servants, and the clergy. However, the estate structure gave room for variation. Thus, noblemen had occupations not only in the intellectual professions and the civil service, but also in the service sector and trades.

Compared to other provincial centres, relatively high female employment rates characterised Tobolsk. This was caused by the presence of educational institutions for women and the participation of women in temporary labour migrations. The share of the employed among single females was twice as high as among those married. In addition to marital status, kinship and cohabitation influenced choice of occupation. However, whereas cohabitation with relatives explained $70 \%$ of occupational choice for females, this factor was significant for only $30 \%$ of males irrespective of their cohabitation with relatives.

In sum, the 1897 census data show us an urban Siberian population getting ready for the dramatic upheavals during the next couple of 
decades. The diversity of employment in all economic sectors characterised a modernising society. Also, the large groups of seasonal work migrants from the countryside provided channels for the diffusion of new ideas. How important the low rate of occupational inheritance from father to son was for the creation of revolutionary groups is difficult to tell. However, it is possible to interpret this as symbolic of a break with century-long traditions of stability.

\section{Список литературы}

Алисов Д. А. Социально-культурный облик «провинциальных столиц» Западной Сибири (конец XIX - начало XX в.) // Изв. Омск. гос. ист.-краеведч. музея. 1998. № 6. C. 263-272.

Брюханова Е. А., Владимиров В. Н. Кодирование исторических профессий. Барнаул : Изд-во АлтГУ, 2015. 220 с.

Брюханова Е. А., Сарафанов Д. Е., Владимиров В. Н., Колдаков Д. В. Подходы к изучению социальной структуры сибирского города на рубеже XIX- XX вв. (по материалам метрических книг Барнаула) // Изв. Урал. федерал. ун-та. Сер. 2. Гуманитарные науки. 2016. Т. 18. № 4 (157). С. 254-270.

Владимиров В. Н., Сарафанов Д. Е., Щетинина А. С. «Новая историческая демография» в России: эволюция или скачок в развитии? // Изв. Урал. федерал. ун-та. Сер. 2. Гуманитарные науки. 2016. Т. 18. № 3 (154). С. 29-54.

Города и поселения в уездах, имеющих 2000 и более жителей / под ред. А. Н. Тройницкого. СПб.: Паровая типолит. Н. Л. Ныркина, 1905. 108 с.

Государственный архив в г. Тобольске. Ф. 417. Оп. 2. Д. 1-8.

Елисеева И. И., Попова И. Н. Начало международного признания российской государственной статистики // Вопросы статистики. 2013. № 8. С. 80-85.

Зиновьев В. П. Сибирь в экономике России XVIII - начала XX вв. // Сибирь в составе России XIX - начала ХХ в. Томск : Изд-во ТГУ, 1999. С. 9-40.

Кадомиев Б. П. Профессиональный и социальный состав населения Европейской России по данным переписи 1897 г. СПб. : Тип. Шредера, 1909. 110 с.

Кауфман A. А. Переселение крестьян в России // Энцикл. словарь Брокгауза и Ефрона. Вып. 23. СПб. : Типолит. И. А. Ефрона, 1900. С. 265-282.

Лаппо Г. М. География городов. М.: ВЛАДОС, 1997. 480 с.

Латкин Н. В. Тобольск // Энцикл. словарь Брокгауза и Ефрона. Вып. 33. СПб. : Тип. Шредера, 1901. С. 384-386.

Ленин В. И. Развитие капитализма в России. Процесс образования внутреннего рынка для крупной промышленности. СПб. : Паллада, 1908. 500 с.

Литвак Б. Г. Перепись населения 1897 года о крестьянстве России: источниковедческий аспект // История СССР. 1990. № 1. С. 114-126.

Лучинский Г. Сибирь // Энцикл. словарь Брокгауза и Ефрона. Вып. 29а. СПб. : Изд. дело ; Брокгауз - Ефрон, 1900. С. 748-814.

Миронов Б. Н. Социальная история России периода империи (XVIII - начало $\mathrm{XX}$ в.) : в 2 т. СПб. : Дмитрий Буланин, 2000. Т. 1. Генезис личности, демократической семьи, гражданского общества и правового государства. 548 с.

Население Тобольска в 1897 г. : [база данных] / рук. проекта В. Н. Владимиров // Архив каф. документоведения, архивоведения и ист. информатики ист. ф-та Алтай. гос. ун-та. Рукопись. Св-во № 2008620393 от 16.01.2009.

Общий свод по империи результатов разработки данных первой всеобщей переписи населения, произведенной 28 января 1897 года / под ред. А. Н. Тройницкого : в 2 т. Т. 2. СПб. : Паровая типолит. Н. Л. Ныркина, 1905. 417 с.

Патканов С. К. Статистические данные, показывающие племенной состав населения Сибири, язык и роды инородцев (на основании данных специальной разработки материала переписи 1897 г.) : в 3 т. СПб. : Тип. Ш. Буссель, 1912. Т. 1. 185 с.

Первая Всеобщая перепись населения Российской империи 1897 г. / под ред. А. Н. Тройницкого. СПб. : Изд. Центр. стат. комитета Мин-ва внутр. дел, 1897-1905. Вып. 72,73 (Т. 2), 74, 75, 76 (Т. 3), 77 (Т. 2), 78, 79, 80.

Профессии и занятия населения Российской империи конца XIX - начала XX века : Анализ данных Первой всероссийской переписи населения 1897 года / рук. проекта Е. Н. Брюханова. URL: http://hcod.asu.ru (дата обращения: 16.02.2017). 
Профессии и занятия населения Российской империи конца XIX - начала XX века (по материалам всероссийской переписи населения 1897 года) : [база данных] / рук. проекта Е. Н. Брюханова // Архив каф. документоведения, архивоведения и ист. информатики ист. ф-та Алтай. гос. ун-та. Рукопись. Св-во № 2014621104 от 07.08.2014.

Семенов В. П. Россия: полное географическое описание нашего отечества : настольная и дорожная книга для русских людей : в 19 т. СПб. : Изд. А. Ф. Девриена, 1907. Т. 11. Западная Сибирь. 591 с.

Скубневский В. А., Гончаров Ю. М. Города Западной Сибири во второй половине XIX - начале XX в. : в 2 ч. Барнаул : Изд-во Алтай. ун-та, 2003. Ч. 1. Население. Экономика. $306 \mathrm{c.}$

Слиозберг Г. Б. Каторга, каторжные работы // Энцикл. словарь Брокгауза и Ефрона. Вып. 14а. СПб. : Типолит. И. А. Ефрона, 1895. С. 756-759.

Учреждение Сибирское (1892) // Свод законов Российской Империи. Вып. 2. СПб. : Изд. книж. магазина «Законоведение», 1912. С. 471-472.

Шиловский М. В. Роль государства в развитии производительных сил Сибири во второй половине XIX - начале XX века: к постановке проблемы // Роль государства в хозяйственном и социокультурном освоении Азиатской России XVII - начала XX века : сб. материалов регион. науч. конф. / отв. ред. М. В. Шиловский. Новосибирск : РИПЭЛ, 2007. С. 5-15.

Ядринцев Н. М. Сибирь как колония в географическом, этнографическом и историческом отношении. СПб. : Изд-во И. М. Сибирякова, 1892.720 с.

Edlund T. K. The Russian National Census of 1897 // Avotaynu. 2000. Vol. 16, № 3. P. 29-39.

Final Report Summary: Research Russian and Soviet Censuses / ed. R. Clem. Florida Intern. Univ., 1984. 44 p. URL: https://www.ucis.pitt.edu/nceeer/1984-627-2-Clem.pdf (mode of access: 28.04.2016).

Kasatkina N., Marcinkevicius A. Russians in Lithuania According to the 1897 and 1923 Censuses : Comparative Analysis // Ethnicity studies. 2008. № 1-2. Pp. 20-63. ISSN $1822-1041$.

Leeuwen M. H. D. Van, Maas I., Miles A. HISCO : Historical International Standard Classification of Occupations. Leuven : Leuven Univ. Press, 2002. 444 p.

Lewis R. A., Rowland R. H., Clem R. S. Nationiality and Poputlation Change in Russia and the USSR : An Evaluation of the Census Data, 1897-1970. N. Y. : Praeger Publ. Inc., $1976.456 \mathrm{p}$.

Naumov I. V. The History of Siberia / ed. D. N. Collins. L. : Routledge, 2006. 256 p.

Rowney D. K., Stockwell E. G. The Russian Census of 1897 : Some Observations on the Age Data // Slavic Rev. 1978. Vol. 37, No 1. P. 217-227.

Spitzer Y. Occupations of Jews in the Pale of Settlement. 2012. URL: http:// yannayspitzer.net/2012/09/30/jewish-occupations-in-the-pale-of-settlement/ (mode of access: 28.04.2016).

The Cambridge History of Russia : in 2 vols / ed. D. Lieven. Cambridge Univ. Press, 2006. Vol. 2. Imperial Russia, 1689-1917. 806 p.

Thorvaldsen G. Away on Census Day : Enumerating the Temporarily Present or Absent// Historical Methods. 2006. Vol. 39 (2). P. 82-96.

Thorvaldsen G. Swedes in Siberian Diaspora // Sibirica : Interdisciplinary J. of Siberian Studies. 2008. Vol. 7 (2). P. 47-66. ISSN 1361-7362.

\section{References}

Alisov, D. A. (1998) Socialjno-kuljturnihyj oblik "provincialjnihkh stolic" Zapadnoyj Sibiri (konec XIX - nachalo XX v.): Izvestiya Omskogo gosudarstvenogo istorikokraevedcheskogo muzeya [The Social and Cultural Image of "Provincial Capitals" in Western Siberia (Late $19^{\text {th }}$ - Early $20^{\text {th }}$ Centuries): News of the Omsk State Local History Museum]. Vol. 6, pp. 263-272.

Bryukhanova, E. A., Sarafanov, D. E., Vladimirov, V. N., Koldakov, D. V. (2016). Podkhodih k izucheniyu socialjnoyj strukturih sibirskogo goroda na rubezhe XIX-XX vv. (po materialam metricheskikh knig Barnaula) [Approaches to the Study of the Siberian City's Social Structure at the Turn of the $20^{\text {th }}$ Century (With Reference to Barnaul Parish Register Books)]: Izvestiya Ural'skogo universiteta. Seriya 2. Gumanitranihe nauki [Izvestia. Ural Federal University Journal. Series 2. Humanities and Arts] Vol. 18, № 4 (157), pp. 254-271. 
Bryukhanova, E. A., Vladimirov, V. N. (2015). Kodirovanie istoricheskikh professiyj [The Coding of Historical Occupations] 220 p. Barnaul, Altai State Univ. publ. house.

Clem, R. S. (ed.) (1984). Final Report Summary: Research Russian and Soviet Censuses. 44 p. Florida Intern. Univ. URL: https://www.ucis.pitt.edu/nceeer/1984-627-2Clem.pdf (mode of access: 28.04.2016).

Edlund, T. K. (2000). The Russian National Census of 1897: Avotaynu. Vol. 16, No 3, pp. 29-39.

Eliseeva, I. I. \& Popova, I. N. (2013). Nachalo mezhdunarodnogo priznaniya rossiyjskoyj gosudarstvennoyj statistiki: Voprosih statistiki [Getting International Recognition of Russia's State Statistics: Statistical Issues]. N 8. pp. 80-85.

Gosudarstvennihyj arkhiv v g. Toboljske [ The State Archives in Tobolsk]. Stock 417. List 2. Dossier 1-8.

Kadomcev, B. P. (1909). Professionaljnihyj $i$ socialjnihyj sostav naseleniya Evropeyjskoyj Rossii po dannihm perepisi $1897 \mathrm{~g}$. [The Occupational and Social Structure of the Population of European Russia according to the 1897 Census Data]. 110 p. St Petersburg. The printing-house of Shreder.

Kasatkina, N., Marcinkevicius, A. (2008). Russians in Lithuania according to the 1897 and 1923 Censuses : Comparative Analysis. In Ethnicity studies, No 1-2, pp. 20-63. ISSN 1822-1041.

Kaufman, A. A. (1900). Pereselenie krestjyan v Rossii: Ehnciklopedicheskiyj slovarj Brokgauza $i$ Efrona [Migration of Peasants in Russia: The Brockhaus and Efron Encyclopaedic Dictionary]. Vol. XXIII, pp. 265-282. St Petersburg. The typolithography of I. A. Efron.

Lappo, G. M. (1997). Geografiya gorodov [Geography of Cities]. 480 p. Moscow. Humanities publishing center Vlados.

Latkin, N. V. (1901). Toboljsk: Ehnciklopedicheskiyj slovarj Brokgauza i Efrona [Tobolsk: The Brockhaus and Efron Encyclopaedic Dictionary]. Vol. XXXIII, pp. 384-386. St Petersburg. The printing-house of Schreder.

Leeuwen, M. H. D.Van \& Maas, I. \& Miles, A. (2002). HISCO : Historical International Standard Classification of Occupations. 444 p. Leuven : Leuven Univ. Press.

Lenin, V. I. (1908). Razvitie kapitalizma v Rossii. Process obrazovaniya vnutrennego rihnka dlya krupnoyj promihshlennosti [The Development of Capitalism in Russia. The Formation of an Internal Market for Large Industry]. 500 p. St Petersburg. Publishing house "Pallada".

Lewis, R. A., Rowland, R. H., Clem, R. S. (1976). Nationality and Population Change in Russia and the USSR : An Evaluation of the Census Data, 1897-1970. 456 p. N. Y., Praeger Publ. Inc.

Lieven, D. (ed.) (2006). The Cambridge History of Russia. Vol. 2. Imperial Russia, 1689-1917. 806 p. Cambridge Univ. Press.

Litvak, K. B. (1990). Perepisj naseleniya 1897 goda o krestjyanstve Rossii: istochnikovedcheskiyj aspekt: Istoriya SSSR [The Population Census of 1897 on the Peasantry in Russia: History of the USSR. N 1. pp. 114-126.

Luchinsky, G. (1900). Sibirj: Ehnciklopedicheskiyj slovarj Brokgauza $i$ Efrona [Siberia: The Brockhaus and Efron Encyclopaedic Dictionary]. Vol. XXIXa, pp. 748-814. St Petersburg. The printing-house of the joint stock company "Publishing industry", Brockhaus - Efron.

Mironov, B. N. (2000). Socialjnaya istoriya Rossii perioda imperii (XVIII-nachalo XXv.) [The Social History of the Russian Empire (18 ${ }^{\text {th }}-$ Early $20^{\text {th }}$ Centuries)]. Vol. $1.548 \mathrm{p}$. St Petersburg. "Dmitriy Bulanin" publishing.

Naselenie Toboljska v 1897 g. : [baza dannykh] [Database "Tobolsk Population in 1897]/ Head of the project V. N. Vladimirov. Registration Certificate 2008620393, 16.01.2009].

Naumov, I. V. (2006). The History of Siberia. Ed. by D. N. Collins. 256 p. L., Routledge.

Patkanov, S. K. (1912). Statisticheskie dannihe, pokazihvayuthie plemennoyj sostav naseleniya Sibiri, yazihk i rodih inorodcev (na osnovanii dannihkh specialjnoyj razrabotki materiala perepisi 1897 g.) [Statistics Showing the Tribal Composition of the Population of Siberia, Language and Ethnicity of Natives (On the Basis of a Special Development of the 1897 Census Data)]. Vol. 1. 185 p. Saint Petersburg. The printing-house "Shc. Bussel".

Professii i zanyatiya naseleniya Rossiyjskoyj imperii konca XIX - nachala XX vekov (po materialam vserossiyjskoyj perepisi naseleniya 1897 goda [Russian Empire Occupations in the Late $19^{\text {th }}$ Early $20^{\text {th }}$ Centuries (Based on the First All-Russia 1897 Population Census] / Head of the project E. N. Bryukhanova. URL: http://hcod.asu.ru (mode of access: 16.02.2017). 
Professii i zanyatiya naseleniya Rossiyjskoyj imperii konca XIX - nachala XX veka : Analiz dannihkh Pervoyj vserossiyjskoyj perepisi naseleniya 1897 goda [Russian Empire Occupations in the Late $19^{\text {th }}-$ Early $20^{\text {th }}$ Centuries : Analysis of the First All-Russia 1897 Population Census]. URL: http://hcod.asu.ru/ (mode of access: 16.02.2017).

Rowney, D. K. \& Stockwell, E. G. (1978). The Russian Census of 1897: Some Observations on the Age Data. In Slavic Rev., Vol. 37. № 1, pp. 217-227.

Semenov, V. P. (1907). Rossiya: polnoe geograficheskoe opisanie nashego otechestva: nastoljnaya i dorozhnaya kniga dlya russkikh lyudeyj. T.11: Zapadnaya Sibirj [Russia: A Complete Geographical Description of Our Motherland: Reference and Road Book for Russian People. V.11: Western Siberia]. 591 p. St Petersburg. Izdanie A. F. Devriena.

Shilovsky, M. V. (2007). Rolj gosudarstva v razvitii proizvoditeljnihkh sil Sibiri vo vtoroyj polovine XIX - nachale XX veka: k postanovke problemih. In Shilovsky, M. V. (ed.) Rolj gosudarstva v khozyayjstvennom i sociokuljturnom osvoenii Aziatskoyj Rossii XVII - nachala XX veka [The Role of the State in the Development of Production in Siberia from the Second Half of the $19^{\text {th }}$ Century to the Early $20^{\text {th }}$ Century: Establishment of the Problematic: Shilovsky, M. V. (ed.) The Role of the State in the Economic and Sociocultural Development of Asian Russia from the $17^{\text {th }}$ Century to the Early $20^{\text {th }}$ Century]. Novosibirsk, RIPAL, pp. 5-15.

Skubnevsky, V. A. \& Goncharov, Yu. M. (2003) Goroda Zapadnoyj Sibiri vo vtoroyj polovine XIX-nachale XXv. Ch. 1. Naselenie. Ehkonomika [Western Siberian Cities in the Second Half of the $19^{\text {th }}$ - Early $20^{\text {th }}$ Centuries. Part I: Population. Economy]. 360 p. Barnaul. Altai State University publishing house.

Sliosberg, H. B. (1895). Katorga, katorzhnihe rabotih : Ehnciklopedicheskiyj slovarj Brokgauza i Efrona [Penal Colony, Hard Labour: The Brockhaus and Efron Encyclopaedic Dictionary]. Vol. XIVa. pp. 756-759. St Petersburg, Typolithography I. A. Efrona.

Spitzer, Y. (2012). Occupations of Jews in the Pale of Settlement. URL: http://yannayspitzer.net/2012/09/30/jewish-occupations-in-the-pale-of-settlement/ (mode of access: 28.04.2016).

Thorvaldsen, G. (2006). Away on Census Day : Enumerating the Temporarily Present or Absent. In Historical Methods, Vol. 39 (2), pp. 82-96.

Thorvaldsen, G. (2008). Swedes in Siberian Diaspora. In Sibirica : Interdisciplinary J. of Siberian Studies, Vol. 7 (2), pp. 47-66. ISSN 1361-7362.

Troynicky, N. A. (ed.) (1904-1905a). Pervaya Vseobthaya perepisj naseleniya Rossiyjskoyj imperii $1897 \mathrm{~g}$. [The First General Census of the Russian Empire]. Vols. LXXII, LXXIII (quire 2), LXXIV, LXXV, LXXVI (quire 3), LXXVII (quire 2), LXXVIII, LXXXIX, LXXX. St Petersburg. The Central Statistical Committee publication of the Ministry of Internal Affairs.

Troynicky, N. A. (ed.) (1905b). Goroda i poseleniya v uezdakh, imeyuthikh 2000 i bolee zhiteleyj [Cities and Settlements in Uyezds with a Population of 2,000 People and over]. St Petersburg. Parovaya tipolitographiya N. L. Nihrkina.

Troynicky, N. A. (ed.) (1905c). Obthiyj svod po Imperii rezuljtatov razrabotki, dannihkh pervoyj vseobtheyj perepisi naseleniya, proizvedennoyj 28 yanvarya 1897 goda Vol. 2 [The Total Results of the First General Census of the Russian Empire, Produced on Jan. 28, 1897]. St Petersburg, Parovaya tipolitographiya N. L. Nihrkina.

Uchrezhdenie Sibirskoe (1892): Svod zakonov Rossiyjskoyj Imperii. (1912). [Uchrezhdeniye Sibirskoe (1892): The Law Code of the Russian Empire]. Vol. 2. Saint Petersburg. Bookshop publ. "Zakonovedenie". Pp. 471-472.

Vladimirov V. N., Sarafanov D. E., Shchetinina A. S. (2016). "Novaya istoricheskaya demografiya" v Rossii: ehvolyuciya ili skachok v razvitii? ["New Historical Demography" in Russia: Evolution or a Leap in Development?]. In Izvestiya Ural'skogo universiteta. Seriya 2. Gumanitranihe nauki [Izvestia Ural Federal University J. Ser. 2. Humanities and Arts]. Vol. 18, № 3 (154). Pp. 29-54.

Yadrincev, N. M. (1892). Sibirj kak koloniya v geograficheskom, ehtnograficheskom $i$ istoricheskom otnoshenii [Siberia as a Colony in Geographical, Ethnographical, and Historical Respects]. 720 p. St Petersburg, Publ. house of I. M. Sibiryakov.

Zinovyev V. P. (1999) Sibirj v ehkonomike Rossii XVIII - nachala XX v.: Sibirj $v$ sostave Rossii XIX - nachala XX $v$. [Siberia in Russia's Economy in the $18^{\text {th }}$ Century Early $20^{\text {th }}$ Centuries: Siberia as a Russian Territory in the $19^{\text {th }}-$ Early $20^{\text {th }}$ Centuries]. Tomsk, The publ. house of Tomsk Univ., pp. 9-40. 